DOI: $10.6060 / \mathrm{mhc} 180171$

\title{
Synthesis and Spectroscopic Studies of Bismuth(III) Iodide Porphyrins
}

\author{
Tatyana A. Ageeva, ${ }^{a}$ Denis V. Golubev, ${ }^{\mathrm{b}}$ Anastasiya S. Gorshkova, ${ }^{\mathrm{b}}$ Andrey M. Ionov, ${ }^{\mathrm{c}}$ \\ Oskar I. Koifman, ${ }^{a}$ Rais N. Mozhchil, ${ }^{c}$ Valentina D. Rumyantseva, ${ }^{\mathrm{b}}$ \\ Aleksandr S. Sigov, ${ }^{\mathrm{b}}$ and Valeriy V. Fomichev'
}

Dedicated to Academician of the Russian Academy of Sciences Prof. I. P. Beletskaya on the occasion of her Birthday

\author{
avanovo State University of Chemistry and Technology, 153000 Ivanovo, Russia \\ ${ }^{\mathrm{b}}$ Moscow Technological University, 119571 Moscow, Russia \\ 'Institute of Solid State Physics RAS, 142432 Chernogolovka, Russia \\ @Corresponding author E-mail:valeryfom@rambler.ru
}

\begin{abstract}
Synthesis of bismuth complexes of etioporphyrin II, protoporphyrin IX dimethyl ester and three tetraphenylporphyrin derivatives in which iodine atom is an extraligand, was carried out. Obtained compounds were characterized by mass spectrometry, UV-vis, ${ }^{1} H$ NMR spectroscopy, and HPLC. The study of X-ray spectra showed that bismuth valence is +3 . Bismuth atom coordinates four nitrogen atoms and one iodine atom. All four nitrogen atoms have equivalent binding energies. IR absorption spectra of free porphyrins bases and their bismuth complexes were studied. The comparison of IR absorption spectra of neat porphyrins shows no significant differences in vibrations of nitrogen-carbon cycles. As for bismuth complexes, vibrations bands of bismuth-iodine bonds $v(B i-I)$ appear at $90-130 \mathrm{~cm}^{-1}$ in the long-wavelength spectra regions, as well as deformation vibrations involving bismuth, iodine and nitrogen atoms $\delta(N B i I)$ with frequencies $150-165 \mathrm{~cm}^{-1}$, deformation vibrations of $\delta[B i N 4]$ pyramid at $\sim 300 \mathrm{~cm}^{-1}$ and stretching vibrations bands of this complex fragment involving deformations of nitrogen-carbon ring, in the region of 335-375 $\mathrm{cm}^{-1}$. Quantum-chemical calculations were conducted including calculations of the vibrational spectra, dipole moments, and charge distribution on atoms (according to Mulliken). It was found that complex of bismuth iodide with etioporphyrin II is the most polar among the studied series compounds.
\end{abstract}

Keywords: Bismuth, porphyrin, metallocomplexes, IR-spectroscopy, XPS, quantum chemical calculations.

\section{Синтез и спектроскопические исследования порфиринатов висмута(III) иодиАа}

\author{
T. А. Агеева, ${ }^{\text {a }}$ А. В. Голубев, ${ }^{\text {b }}$ А. С. Горшкова, ${ }^{\text {b }}$ А. М. Ионов, ${ }^{\text {c }}$ О. И. Койдрман, ${ }^{\text {a }}$

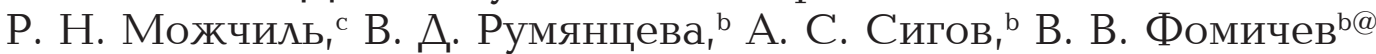 \\ а Ивановский государственный химико-технологический университет, 153000 Иваново, Россия \\ ' Московский технологический университет, 119571 Москва, Россия \\ ' Институт физики твердого тела РАН, 142432 Черноголовка, Московская обл., Россия \\ ${ }^{\circledR}$ E-mail:valeryfom@rambler.ru
}

Осуществлен синтез висмутовых комплексов этиопорфирина II, ДМЭ протопорфирина IX и трех производных тетрафенилпорфина, в которых в качестве экстралиганда выступает атом йода. Полученные соединения охарактеризованы методами масс-спектрометрии, электронной и ${ }^{1}$ Н ЯМР спектроскопии, ВЭЖХ. Изучение РФЭ-спектров комплексов показало, что висмут имеет валентность +3. Атом висмута координирует четыре атома азота и один атом йода, при этом в комплексах все энергии связей электронов атомов азота выровнены. Изучены ИК спектры поглощения свободных оснований порфиринов и их висмутовых комплексов. Сравнение 
ИК спектров поглощения исходных порфиринов показывает, что существенных различий в колебаниях азотноуглеродного ичиклов не наблюдается. При переходе к висмутовым комплексам в длинноволновых областях спектров появляются полосы колебаний связей висмут-йод v(Bi-I) при 90-130 см-1, а также деформационных колебаний с участием атомов висмута, йода и азота $\delta$ (NBiI) с частотами 150-165 см-1, деформационных колебаний пирамиды $\delta\left[\mathrm{BiN}_{4}\right]$ при $\sim 300 \mathrm{~cm}^{-1}$ и в области 335-375 см-1 полосы валентньх колебаний этого фрагмента комплекса с участием деформаџий азотно-углеродного кольца. Выполнень квантовохимические расчеты, в том числе рассчитаны колебательные спектры, дипольные моменты и распределение зарядов на атомах (по Малликену). Наиболее полярным из полученных соединений является комплекс йодида висмута с этиопорфирином II.

Ключевые слова: Висмут, порфирин, металлокомплексы, ИК-спектроскопия, РФЭС, квантовохимические расчеты.

\section{Introduction}

Interest towards bismuth containing complexes to a large degree is due to their use in medicine. First reports about application of bismuth containing salts for treatment of dyspepsia appeared in $1786 .{ }^{[1]}$ Currently, such medicinal compounds of bismuth as de-nol, desmol, tribimol, vicair, vikalin and etc., are well-known for treatment of gastritis and peptic ulcer disease. ${ }^{[2,3]}$ Recently, antitumor effectiveness of bismuth complex with diethylenetriaminepentaacetic acid was demonstrated in binary radiation therapy. ${ }^{[4]}$

First syntheses of bismuth complexes with porphyrins were described by A. Treibs in 1969. ${ }^{[5]}$ The bismuth ion insertions into mesoporphyrin IX dimethyl ester and etioporphyrin II were carried out in pyridine in the presence of bismuth nitrate. However, the complexes structures were not fully established.

Later, Buchler ${ }^{[6]}$ described the synthesis of bismuth octaethylporphyrin (OEP) complex also in pyridine with bismuth nitrate. The authors attributed to bismuth in OEP$\mathrm{Bi}(\mathrm{O}) \mathrm{NO}_{2}$ the oxidation state $(\mathrm{V})$. The complex was found to be decomposing upon recrystallization or treatment with dilute hydrochloric acid.

Subsequently, complexes of $\mathrm{Bi}$ (III) with substituted tolyl- and methoxy-derivatives of tetraphenylporphyrin (TPP) in chloroform with bismuth chloride were synthesized. ${ }^{[7]}$ At the same time, dimeric porphyrin structures bound together by $\mathrm{Bi}_{2} \mathrm{Cl}_{6}$ fragment were isolated.

The bismuth(III) ion insertion into porphyrin macrocycle in dimethylformamide and pyridine was carried out using bismuth nitrate and bismuth triflate. ${ }^{[8]}$ OEP, TPP, tetramesityl- and tetra(4-tolyl)porphyrins were chosen as free bases. It turned out that complexes with nitro group are more stable than chlorides and bromides, the latter complexes are not stable and sensitive to light and water. The use of bismuth triflate led to increase in complexes stability and syntheses yield (75\% - OEP, 50\% - TPP, 70\% - tolylporphyrin). This is due to steric protection provided by relatively large triflate ligand.

In recent years, bismuth(III) compounds containing radioactive isotopes ${ }^{212} \mathrm{Bi}\left(\mathrm{t}_{1 / 2}=60 \mathrm{~min}\right)$ and ${ }^{213} \mathrm{Bi}\left(\mathrm{t}_{1 / 2}=45 \mathrm{~min}\right)$, have been used in cancer therapy. ${ }^{[9-11]}$ Bismuth drugs in the form of porphyrins complexes have found application as chemotherapeutic agents for leishmania treatment. ${ }^{[12]}$

$\mathrm{Bi}^{\mathrm{III}} \mathrm{NO}_{3}$ complexes with TPP and 5,10,15,20-tetrakis (4-methoxycarbonylphenyl)porphyrin have been studied.
The compounds were characterized by UV-vis, ${ }^{1} \mathrm{H}$ NMR spectroscopy, mass spectrometry and elemental analysis.

Along with hydrophobic bismuth complexes, kinetically labile complexes with tetrasulfophenylporphyrin in an anion form and 5,10,15,20-tetrakis(1-methyl-4-pyridyl)porphyrin in a cation form were synthesized..$^{[13]}$

It is well-known that in its complexes bismuth has oxidation states +3 and +5 , and its coordination number can vary from 3 to 10 . Due to the large ionic radius of bismuth(III) $1.03 \AA$, it can not fit in porphyrin macrocycle plane, so bismuth is located above it. This fact leads to lability of bismuth-porphyrin complexes.

The objective of the study reported here was to search for planar complexes with a strongly polarized «apix» metal-ligand bond - promising elements for a new electronic materials design. From this point of view bismuth(III) compounds with its spatially localized $6 s^{2}$ orbital are the perspective targets. The problem solution involves the synthesis of various $\mathrm{Bi}^{\mathrm{III}} \mathrm{I}$-porphyrins and their study by IR and X-ray spectroscopy methods, as well as analysis of porphyrin molecule spatial configuration influence on a possibility of complexation with bismuth iodide. Etioporphyrin II, whose bismuth(III) iodide complex thermal stability was studied previously, ${ }^{[14]}$ protoporphyrin IX dimethyl ester (PP IX DME) (1) and three tetraphenylporphyrin derivatives (2-4) differ by substituents on phenyl rings and on macrocycle periphery, were selected as research objects (Figure 1).

\section{Experimental}

Electronic absorption spectra were recorded using UVvis spectrophotometer Helios Alpha Local Control System («TermoSpectronic», USA). Mass spectra were measured using Ultraflex TOF/TOF device (Bruker Daltonics, Germany), a matrix was 2,5-dihydroxybenzoic acid. The ${ }^{1} \mathrm{H}$ NMR spectra in a $\delta(\mathrm{ppm})$ scale were obtained with a Bruker DPX-300 (300 MHz) (Germany) in deuterochloroform. HPLC was performed using Waters «Breeze» chromatograph on a Nova-Pack column with $18.4 \mu \mathrm{m}$, $4.6 \times 150 \mathrm{~mm}$. A substance was eluted with a mixture of wateracetonitrile (6:4), was detected at $400 \mathrm{~nm}$. Silica gel Kieselgel 60 (Merck, Germany) was used for a column chromatography. X-Ray photoelectron spectroscopy (XPS) studies were performed using Kratos AXIS Ultra DLD electronic spectrometer (Kratos Analytical, UK) with a monochromatized X-ray source Al Ka $(\mathrm{h} v=1486.6 \mathrm{eV})$. FT-IR spectra were recorded using EQUINOX 55 spectrometer (Bruker, Germany). For study in the mid-IR- 


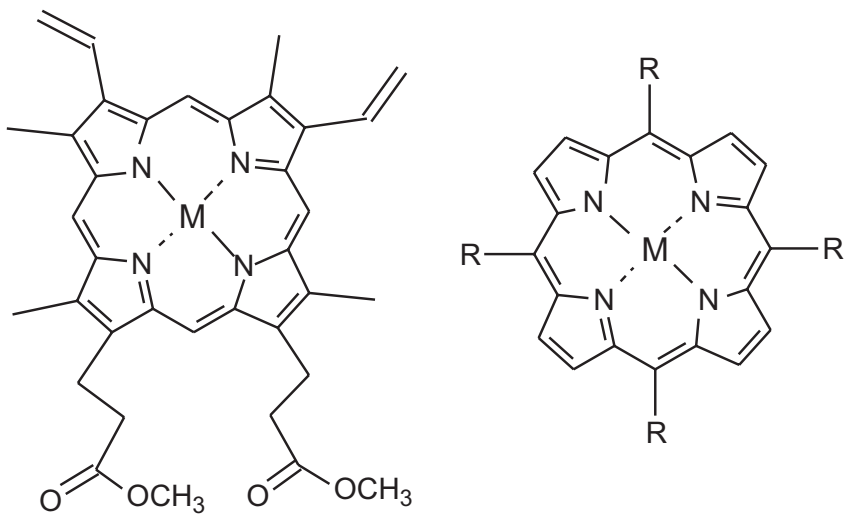

1. a: $\mathrm{M}=2 \mathrm{H}$

b: $\mathrm{M}=\mathrm{BiI}$

2. $\mathrm{a}: \mathrm{R}=\left(4-\mathrm{CO}_{2} \mathrm{MePh}\right) ; \mathrm{M}=2 \mathrm{H}$

b: $\mathrm{R}=\left(4-\mathrm{CO}_{2} \mathrm{MePh}\right) ; \mathrm{M}=\mathrm{BiI}$
3. a: $\mathrm{R}=$ mesytyl; $\mathrm{M}=2 \mathrm{H}$

b: $\mathrm{R}=$ mesytyl; $\mathrm{M}=\mathrm{BiI}$

4. a: $\mathrm{R}=\mathrm{C}_{6} \mathrm{~F}_{5} ; \mathrm{M}=2 \mathrm{H}$

b: $\mathrm{R}=\mathrm{C}_{6} \mathrm{~F}_{5} ; \mathrm{M}=\mathrm{BiI}$

Figure 1. Structural formulas of reviewed porphyrins and their bismuth complexes.

range $\left(4000-700 \mathrm{~cm}^{-1}\right)$ the samples were prepared in the form of a powder with $\mathrm{KBr}$ and spectra were recorded using a diffuse reflection attachment EasiDiffTM Diffuse Reflectance Accessory (PIKE Technologies, Inc.). For study in the far-IR range (700$50 \mathrm{~cm}^{-1}$ ) the samples were prepared in the form of a suspension in vaseline on windows of high-density polyethylene. The spectra were processed using OPUS6.0 software.

The geometry optimization and the absorption frequencies calculation were performed with the Priroda 16 software package ${ }^{[15-17]}$ using the density functional method: $\mathrm{dft} / \mathrm{pbe} /$ L1 in the full-electron scalar-relativistic Dyall Modified Dirac approximation. The optimized geometric structure image was prepared with the Chemcraft software.

\section{General methods of bismuth iodide porphyrin complexes synthesis}

Protoporphyrin IX DME (PP IX DME) (1a) was obtained from blood hemin following the previously described method. ${ }^{[18]}$ Porphyrin 2a was synthesized from pyrrole and 4-formylbenzoic acid methyl ester by Rothemund method in propionic acid. ${ }^{[19]}$ 5,10,15,20-Tetrakis-mesitylporphyrin (TMP) (3a) and pentafluorophenylporphyrin $\left(\mathrm{TPPF}_{20}\right)(\mathbf{4 a})$ were prepared by Lindsey method. ${ }^{[20]}$

To a boiling porphyrin pyridine solution in argon stream, a 5-10 fold excess of bismuth iodide was added, and the mixture was boiled for 3-7 hours. The reaction was monitored spectrophotometrically and by TLC on Silufol plates. At the end of the reaction, the solvent was evaporated to dryness in vacuum. The isolated red-brown solid was treated with chloroform. The bismuth iodide and bismuth oxoiodide precipitate was filtered off, washed with chloroform and discarded. The green color mother liquor was concentrated and chromatographed on a silica gel column using solution of $\mathrm{CH}_{2} \mathrm{Cl}_{2}$ and petroleum ether (3:2). At this step the unreacted free porphyrin base was separated. The bismuth complexes were eluted with solution of $\mathrm{CH}_{2} \mathrm{Cl}_{2}-i-\mathrm{PrOH}$ (20:1), evaporated and recrystallized from methylene chloride-methanol.

BiI-PP IX DME (1b). Yield $28 \%$. UV-vis $\left(\mathrm{CHCl}_{3}\right) \lambda_{\max } \mathrm{nm}$ (lge): 477(4.85), 586 (4.07). $\mathrm{m} / \mathrm{z} 797.468[\mathrm{M}-\mathrm{I}]^{+}$. Calculated for $\mathrm{C}_{36} \mathrm{H}_{36} \mathrm{~N}_{4} \mathrm{O}_{4} \mathrm{Bi} 797.686$.

BiI-TPP $\left(4-\mathrm{COOCH}_{3} \mathrm{Ph}\right)(\mathbf{2 b})$. Yield $63 \%$. UV-vis (DMSO) $\lambda_{\max } \mathrm{nm}(\lg \varepsilon)$ : $472(5.03), 600(3.87), 646(3.96) . \mathrm{m} / z 1053.281[\mathrm{M}-\mathrm{I}]^{+}$. Calculated for $\mathrm{C}_{52} \mathrm{H}_{36} \mathrm{~N}_{4} \mathrm{O}_{8} \mathrm{Bi}$ 1053.862. ${ }^{1} \mathrm{H}$ NMR ppm: $8.89(8 \mathrm{H}$, s, $\beta-\mathrm{H}), 8.4\left(8 \mathrm{H}, \mathrm{m}, \mathrm{o}-\mathrm{C}_{6} \mathrm{H}_{5}\right) .8 .17\left(8 \mathrm{H}\right.$, br. s , m- $\left.\mathrm{C}_{6} \mathrm{H}_{5}\right), 4.2(12 \mathrm{H}$, s, $\mathrm{COOCH}_{3}$ ). HPLC: RT $17.856 \mathrm{~min}$; complex content $98.33 \%$.

BiI-TMP (3b). Yield $50.7 \%$. UV-vis $\left(\mathrm{CHCl}_{3}\right) \lambda_{\max } \mathrm{nm}(\lg \varepsilon)$ : 474 (5.17), 605 (3.91), 653 (4.01). $\mathrm{m} / z 989.008[\mathrm{M}-\mathrm{I}]^{+}$. Calculated for $\mathrm{C}_{56} \mathrm{H}_{52} \mathrm{~N}_{4} \mathrm{Bi}$ 990.064. ${ }^{1} \mathrm{H}$ NMR ppm: 8.98 ( $\left.8 \mathrm{H}, \mathrm{s}, \beta-\mathrm{H}\right), 7.38$ $\left(4 \mathrm{H}, \mathrm{s}, \mathrm{m}-\mathrm{H}-\mathrm{C}_{6} \mathrm{H}_{5}\right), 7.28\left(4 \mathrm{H}, \mathrm{s}, \mathrm{m}-\mathrm{H}-\mathrm{C}_{6} \mathrm{H}_{5}\right), 2.65\left(12 \mathrm{H}, \mathrm{s}, \mathrm{o}-\mathrm{CH}_{3}-\right.$ $\mathrm{Ph}), 2.15\left(12 \mathrm{H}, \mathrm{s}, \mathrm{o}-\mathrm{CH}_{3}-\mathrm{Ph}\right), 1.27\left(12 \mathrm{H}, \mathrm{s}, \mathrm{p}-\mathrm{CH}_{3}-\mathrm{Ph}\right)$.

BiTPPF $_{20}(4 \boldsymbol{b})$. Yield $16.4 \%$. UV-vis $\left(\mathrm{CHCl}_{3}\right) \lambda_{\max } \mathrm{nm}$ $(\lg \varepsilon): 473$ (5.18), 589 (4.13). $\mathrm{m} / z 1180.550[\mathrm{M}-\mathrm{I}]^{+}$. Calculated for $\mathrm{C}_{44} \mathrm{H}_{8} \mathrm{~N}_{4} \mathrm{~F}_{20} \mathrm{Bi} 1181.51 .{ }^{1} \mathrm{H}$ NMR ppm: $9.0(8 \mathrm{H}, \mathrm{s}, \beta-\mathrm{H})$.

\section{Results and Discussion}

Analysis of the results of chemical syntheses of bismuth porphyrin complexes indicates that derivatives of tetraarylporphyrins have higher metallocomplexes yields than protoporphyrin containing two labile vinyl groups. The yield of etioporphyrin II (36.8\%) occupies an intermediate position. ${ }^{[14]}$ The presence of ester groups in meso-tetraarylporphyrin increases its stability and, accordingly, leads to higher yield of the bismuth complex. The use of the bismuth pentafluorophenylporphyrin (4b) complex seems to be the least promising because of its spatially distorted configuration and lower stability.

Table 1. The binding energies of the core electrons of bismuth triiodide molecules, porphyrins and their iodide complexes with bismuth (eV).

\begin{tabular}{|c|c|c|c|c|}
\hline \multirow{2}{*}{ Compound } & \multicolumn{4}{|c|}{ Elements (photoelectron line) } \\
\hline & N1s & $\mathrm{C} 1 \mathrm{~s}$ & $\mathrm{Bi} 4 \mathrm{f}$ & $\mathrm{I} 3 \mathrm{~d}$ \\
\hline $\mathrm{BiI}_{3}$ & & & $164.5 ; 159.2$ & $630.8 ; 619.6$ \\
\hline PP IX DME & $399.5 ; 397.4$ & 284.7 & & \\
\hline BiI-PP IX DME & 398.5 & 284.7 & $164.4 ; 159.2$ & $630.3 ; 618.8$ \\
\hline EP II & $399.4 ; 397.4$ & $287.5 ; 284.7$ & & \\
\hline BiI-EP II & 398.4 & 284.7 & $164.4 ; 159.2$ & $630.3 ; 618.7$ \\
\hline ТPP(4-COOMePh) & $400.1 ; 398.0$ & $287.8 ; 284.8$ & & \\
\hline BiI-TPP(4-COOMePh) & 398.6 & 284.8 & $164.7 ; 159.3$ & $630.3 ; 618.8$ \\
\hline $\mathrm{TPPF}_{20}$ & $400.02 ; 398.2$ & $284.6 ; 285.8 ; 288$ & & \\
\hline BiI-TPPF ${ }_{20}$ & 398.8 & $284.7 ; 284.4 ; 288$ & $164.7 ; 159.5$ & $630.3 ; 618.7$ \\
\hline
\end{tabular}


The XPS data for the metal-containing and metal-free porphyrin compounds and the binding energies of the core electrons of nitrogen, carbon, bismuth and iodine atoms of the synthesized porphyrins samples and their iodide complexes with bismuth are summarized in Table 1 while the spectra are shown in Figure 2.

One can note the existence of two nitrogen atoms types (aza- and pyrro-) in the structure of all porphyrins molecules. Moreover, the binding energies of N1s electrons of nitrogen atoms in tetraphenylporphyrins are higher than the binding energies of proto- and etioporphyrins nitrogen atoms. As for the metallocomplexes spectra, degeneracy of the corresponding states is observed. Nevertheless, the binding energy of 1s-electrons of nitrogen atoms in the complexes, assuming the average value, remains higher for compounds with tetraphenylporphyrins. Doublets with the energy values close to the binding energies in bismuth triiodide were registered for $4 \mathrm{f}$-electrons of bismuth, while the doublets for tetraphenylporphyrin complexes have slightly higher values. XPS spectra of BiI-PP IX DME and PP IX DME are shown in Figure 2.

Therefore, we conclude that the bismuth atom in the prepared complexes is coordinated with four nitrogen atoms with equal electron binding energies and one iodine atom. Taking into account the stereo-active unshared pair of $6 \mathrm{~s}^{2}$ electrons, the characteristic for Bi coordination number 6 is realized.

The comparison of IR absorption spectra of neat porphyrins considered in this paper, shows no significant differences in vibrations of nitrogen-carbon cycle. Frequencies of the deformational vibrations are summarized in Table 2. General increase in the number of observed adsorption bands parallels the increase in molecules complexity and the increase in the number of different CCC fragments, including aromatic rings.

One can note a slight increase in the cycle deformation vibrations frequencies $\delta(\mathrm{CNC})$ upon transition to the spectrum of tetraphenylporphyrin (2a). The picture naturally changes during the transition to bismuth complexes (Fig- ure 3). The vibration bands of $v(\mathrm{Bi}-\mathrm{I})$ bonds with frequencies $90-130 \mathrm{~cm}^{-1}$ are observed in the long-wave spectra regions; motions of these heavy atoms perturb additional deformational vibrations of the nitrogen-carbon ring. The bands of deformational vibrations with the participation of bismuth, iodine and nitrogen atoms $\delta(\mathrm{NBiI})$ with frequencies $150-165 \mathrm{~cm}^{-1}$ lie somewhat higher. The deformation vibration frequencies of the pyramid [BiN4] lie even higher. And finally, the frequencies of stretching vibrations of this complex fragment involving deformations of the nitrogencarbon ring, are in the region $335-375 \mathrm{~cm}^{-1}$.

The quantum-chemical calculations were performed (Table 3), namely, the geometries of free bases and complexes with bismuth iodide were optimized; vibrational spectra, dipole moments and charge distributions on atoms (according to Mulliken) were calculated.

Calculated atomic charges indicate that the complex formation leads to the polarization of the porphyrin cycle. A positive charge increases one and a half times on carbon atoms associated with nitrogen. A negative charge on nitrogen atoms increases by almost one and a half times. At the same time, if the values of charges on nitrogen are equal for porphyrins molecules, then the transition to complexes leads to the differentiation of charges. The difference reaches $10 \%$. A significant positive charge is established for bismuth atoms in iodide complexes -1.53 , and even higher charge in hydroxy-complex $-1.58 .^{[14]}$ The latter is compensated by a large negative charge on oxygen. But the hydroxygroup charge as a whole is close to the negative charge on iodine atoms in iodide complexes.

The calculation of dipole moments gives the following values: 6.47 D for BiI-EP II and 3.87 D for BiI-TPPF ${ }_{20}$.

It follows from the analysis of the populations of orbitals that 6s-electrons are localized to a large extent. The population of molecular orbitals for bismuth atoms is $1.80-1.86$ e. At the same time, bismuth plays a role of an electron density translator from porphyrin cycle atoms to iodine atom.

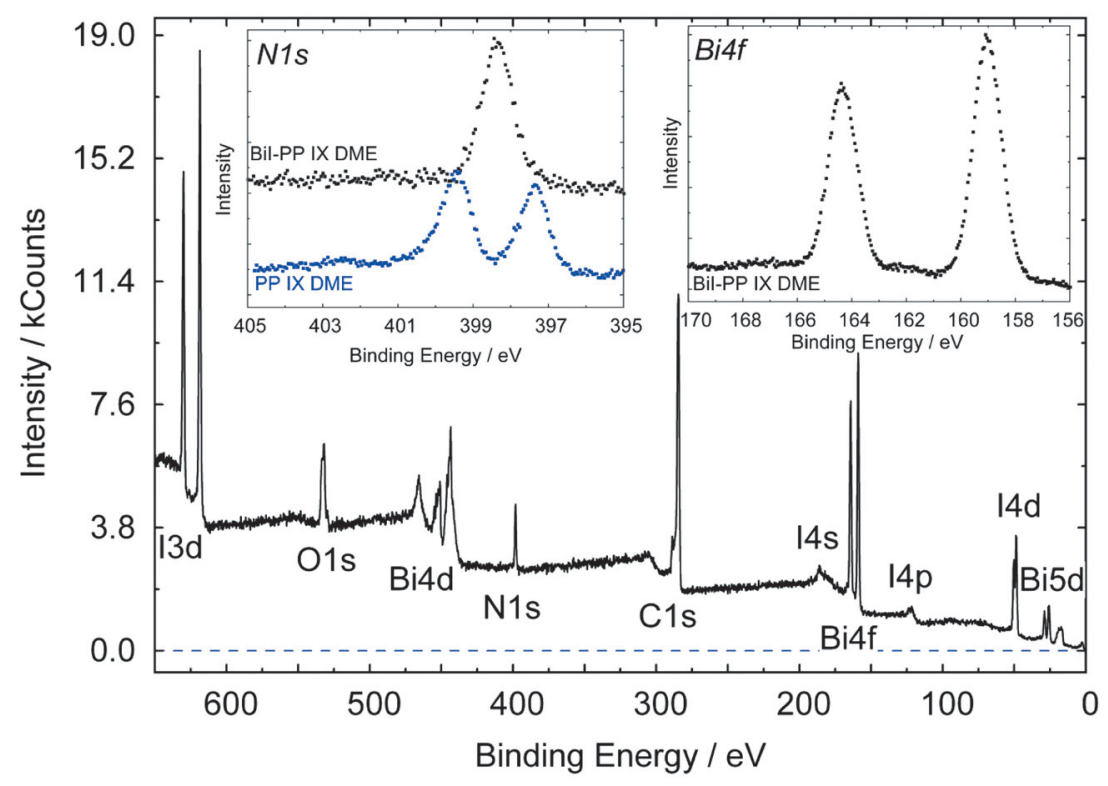

Figure 2. XPS spectra of BiI-PP IX DME (black) and PP IX DME (blue). 
Table 2. The vibrational frequencies of bismuth porphyrins complexes in the region of porphyrin cycle oscillations $\left(\mathrm{cm}^{-1}\right)$.

\begin{tabular}{|c|c|c|c|c|c|}
\hline $\begin{array}{l}\text { BiI-PP IX DME } \\
\qquad v, \mathrm{~cm}^{-1}\end{array}$ & $\begin{array}{l}\text { BiI-TMP } \\
v, \mathrm{~cm}^{-1}\end{array}$ & $\begin{array}{c}\text { BiI-TPPF }{ }_{20} \\
v, \mathrm{~cm}^{-1}\end{array}$ & $\begin{array}{c}\text { BiI-TPP(4-COOMePh) } \\
v, \mathrm{~cm}^{-1}\end{array}$ & $\begin{array}{l}\text { BiI-EP I[ }{ }^{[14]} \\
\quad v, \mathrm{~cm}^{-1}\end{array}$ & Assignment* \\
\hline 110 & 117 & $\begin{array}{c}91 \\
103\end{array}$ & 80 & 101 & $v(\mathrm{BiI})+v_{\mathrm{as}}(\mathrm{BiN})$ \\
\hline 132 & 134 & $\begin{array}{l}122 \\
137\end{array}$ & $\begin{array}{l}120 \\
137\end{array}$ & 125 & $\delta(\mathrm{IBiNC})+v(\mathrm{BiN})+v(\mathrm{BiI})$ \\
\hline 165 & 161 & 153 & - & 156 & $v(\mathrm{BiI})+v(\mathrm{BiN})+\delta(\mathrm{BiNC})$ \\
\hline & 182 & 176 & 175 & 173 & $v(\mathrm{BiN})+\delta(\mathrm{BiNC})+\delta(\mathrm{IBiN})$ \\
\hline $\begin{array}{l}226 \\
248\end{array}$ & $\begin{array}{l}217 \\
236\end{array}$ & $\begin{array}{l}202 \\
212 \\
247\end{array}$ & $\begin{array}{l}204 \\
242\end{array}$ & 228 & $\delta(\mathrm{BiNC})+\delta(\mathrm{IBiN})$ \\
\hline 226 & 260 & 267 & 253 & 277 & $\delta(\mathrm{BiNC})$ \\
\hline $\begin{array}{l}248 \\
300\end{array}$ & $\begin{array}{l}290 \\
314\end{array}$ & $\begin{array}{l}280 \\
302\end{array}$ & $\begin{array}{l}280 \\
293 \\
305 \\
\end{array}$ & 301 & $\delta(\mathrm{NBiN})+\delta($ ring $)$ \\
\hline $\begin{array}{l}348 \\
362\end{array}$ & $\begin{array}{l}336 \\
375\end{array}$ & $\begin{array}{l}340 \\
368 \\
372\end{array}$ & 346 & $\begin{array}{l}346 \\
373\end{array}$ & $v(\mathrm{BiN})+\delta(\mathrm{BiNC})$ \\
\hline 427 & $\begin{array}{l}419 \\
443\end{array}$ & $\begin{array}{l}397 \\
416 \\
443\end{array}$ & $\begin{array}{l}396 \\
421 \\
443\end{array}$ & $\begin{array}{l}399 \\
418\end{array}$ & $\delta(\mathrm{CNC})+\delta($ ring $)+\delta(\mathrm{NBiN})$ \\
\hline 500 & $\begin{array}{l}470 \\
487\end{array}$ & $\begin{array}{l}471 \\
504 \\
523\end{array}$ & $\begin{array}{l}467 \\
490\end{array}$ & $\begin{array}{l}461 \\
492\end{array}$ & $\delta(\mathrm{CNC})+(\delta$ ring $)+\delta(\mathrm{NBiN})$ \\
\hline 568 & 569 & $\begin{array}{l}566 \\
582\end{array}$ & 572 & 561 & $\delta(\mathrm{CNC})+\delta($ ring $)$ \\
\hline $\begin{array}{l}643 \\
687\end{array}$ & $\begin{array}{l}640 \\
667 \\
690\end{array}$ & $\begin{array}{l}646 \\
670 \\
682\end{array}$ & $\begin{array}{l}637 \\
650 \\
684\end{array}$ & $\begin{array}{l}624 \\
662 \\
679\end{array}$ & $\delta(\mathrm{CNC})+\delta($ ring $)$ \\
\hline
\end{tabular}

* Vibrational frequencies assignments were done on a basis of quantum-chemical calculations results.

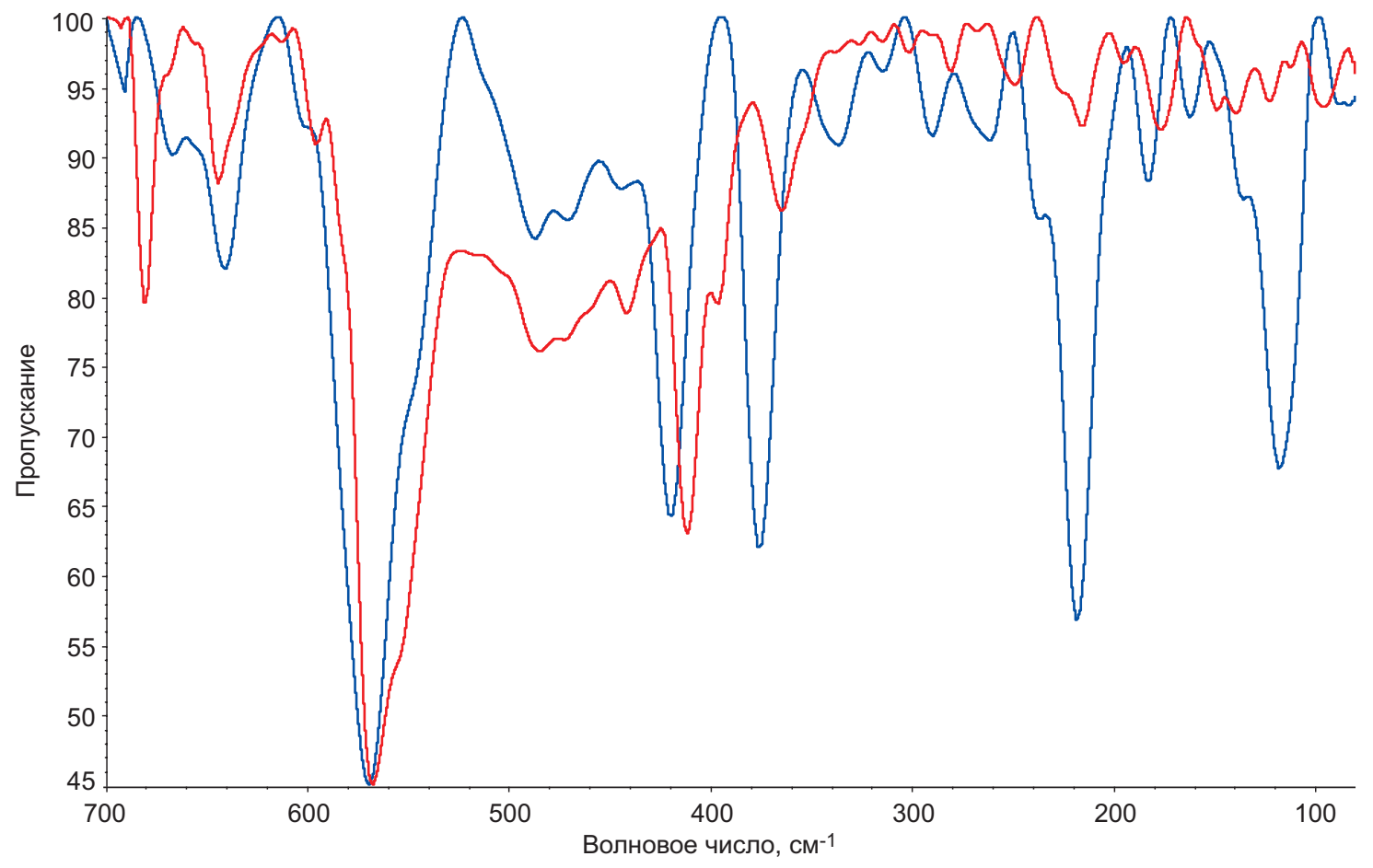

Figure 3. The FT-IR spectra of TMP (3a) (red) and BiI-TMP complex (3b) (blue) in the frequency range of porphyrin cycle oscillations. 
Table 3. Values of Mulliken charges on porphyrin cycle atoms (e).

\begin{tabular}{|c|c|c|c|c|c|c|c|c|c|}
\hline \multicolumn{2}{|c|}{ EP II } & \multicolumn{2}{|c|}{ BiI-EP II } & \multicolumn{2}{|c|}{ BiOH-EP II } & \multicolumn{2}{|c|}{$\mathrm{TPPF}_{20}$} & \multicolumn{2}{|c|}{ BiI-TPPF $_{20}$} \\
\hline atom & charge & atom & charge & atom & charge & atom & charge & atom & charge \\
\hline N1 & -0.4267 & N1 & -0.6838 & N1 & -0.6815 & N1 & -0.4209 & N1 & -0.6451 \\
\hline $\mathrm{C} 4$ & 0.1549 & $\mathrm{C} 4$ & 0.2187 & $\mathrm{C} 4$ & 0.2070 & $\mathrm{C} 3$ & 0.1864 & $\mathrm{C} 3$ & 0.2789 \\
\hline $\mathrm{C} 5$ & 0.1606 & $\mathrm{C} 5$ & 0.2293 & $\mathrm{C} 5$ & 0.2156 & $\mathrm{C} 4$ & 0.1880 & $\mathrm{C} 4$ & 0.2638 \\
\hline N2 & -0.4258 & $\mathrm{~N} 2$ & -0.6525 & $\mathrm{~N} 2$ & -0.6212 & $\mathrm{~N} 2$ & -0.4210 & $\mathrm{~N} 2$ & -0.6778 \\
\hline $\mathrm{C} 7$ & 0.1544 & $\mathrm{C} 7$ & 0.2395 & $\mathrm{C} 7$ & 0.2315 & C6 & 0.1880 & C6 & 0.2504 \\
\hline $\mathrm{C} 8$ & 0.1624 & $\mathrm{C} 8$ & 0.2621 & $\mathrm{C} 8$ & 0.2681 & $\mathrm{C} 7$ & 0.1862 & $\mathrm{C} 7$ & 0.2439 \\
\hline $\mathrm{C} 10$ & 0.1554 & $\mathrm{C} 10$ & 0.2623 & $\mathrm{C} 10$ & 0.2697 & C9 & 0.1862 & C9 & 0.2408 \\
\hline N3 & -0.4259 & N3 & -0.6838 & N3 & -0.6821 & N3 & -0.4208 & N3 & -0.6383 \\
\hline $\mathrm{C} 14$ & 0.1614 & $\mathrm{C} 14$ & 0.2399 & $\mathrm{C} 14$ & 0.2333 & $\mathrm{C} 12$ & 0.1879 & $\mathrm{C} 12$ & 0.2446 \\
\hline $\mathrm{C} 16$ & 0.1546 & $\mathrm{C} 16$ & 0.2295 & $\mathrm{C} 16$ & 0.2167 & $\mathrm{C} 14$ & 0.1881 & $\mathrm{C} 14$ & 0.2607 \\
\hline N4 & -0.4260 & N4 & -0.6529 & N4 & -0.6229 & N4 & -0.4210 & N4 & -0.6780 \\
\hline \multirow[t]{4}{*}{$\mathrm{C} 24$} & 0.1613 & $\mathrm{C} 24$ & 0.2187 & $\mathrm{C} 24$ & 0.2074 & $\mathrm{C} 17$ & 0.1864 & $\mathrm{C} 17$ & 0.2777 \\
\hline & & Bi1 & 1.5332 & Bil & 1.5813 & & & Bi1 & 1.5280 \\
\hline & & I1 & -0.6503 & $\mathrm{O} 1$ & -0.7985 & & & I1 & -0.5685 \\
\hline & & & & H37 & 0.2201 & & & & \\
\hline
\end{tabular}

It should be noted that BiI-TPP(4-COOMePh) and BiIEP II complexes have the greatest $\mathrm{Bi}-\mathrm{I}$ bond polarity, that agrees with the maximum charge difference and the lower bond residual covalence.

The dipole moment vector of the molecule (Figure 4) deviates from the Bi-I bond direction under the influence of 6 s-electrons.

Thus, the obtained results indicate that the complex of bismuth iodide with etioporphyrin II is the most polar of the studied compounds.

\section{Conclusions}

The comparative study of bismuth porphyrin complexes demonstrated that peripheral environment in a porphyrin macrocycle has a significant effect on a metallocomplexes yield. It was shown that the distortion of a spatial configuration in the case of pentafluorophenylporphyrin leads to a significant decrease in the complex yield. The low complex yield can be caused not only by its distorted structure, but also by the presence of electron-acceptor substituents weakening the $\mathrm{Bi}-\mathrm{N}$ bound. In IR-spectra the vibrational bands with a participation of bismuth-iodine and bismuthnitrogen bonds appear in the long-wave regions of the spectra due to coordination of bismuth ion with porphyrin macrocycles. The electronic structure features of Bi4f, N1s, C1s and $\mathrm{I} 3 \mathrm{~d}$ core levels were studied and the electronic structure change was revealed due to the insertion of central bismuth atom, which coordinates four nitrogen atoms (with equal electron binding energies) and one iodine atom. On the basis of quantum-chemical calculations, it was shown that the complex formation leads to the porphyrin cycle polarization. Dipole moments for all bismuth complexes have

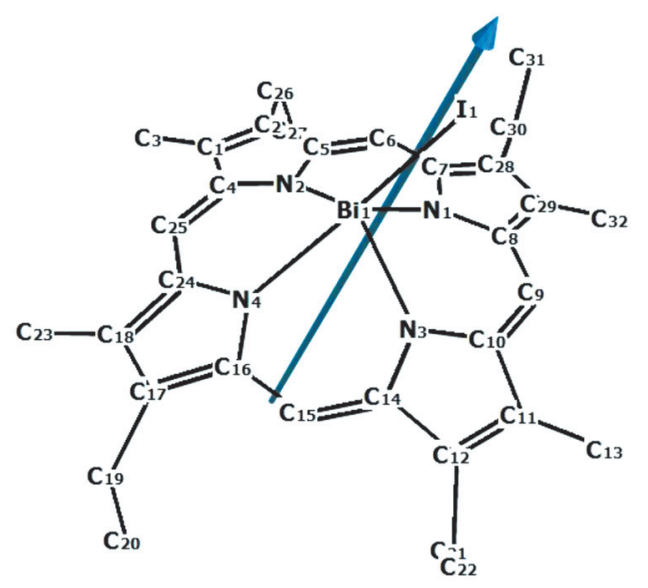

Figure 4. Optimized geometry of bismuth(III) iodide complex with etioporphyrin II (the dipole moment vector is indicated).

been determined, and the bismuth complex of etioporphyrin II appears to be the most polar.

Acknowledgements. The work was carried out within the framework of the State task of the Ministry of Education and Science of the Russian Federation (project № 4.9596.2017/8.9). The work was carried out using the equipment of the Collective Use Center of the Moscow Technological University.

\section{References}

1. Yang Y., Ouyang R., Xu L., Li W., Feng K., Ouyang L., Yang Z., Zhou S., Miao Y. J. Coord Chem. 2015, 68, 379-397. 
2. Yukhin Yu.M., Mikhailov Yu.I. Chemistry of Bismuth Compounds and Materials. Novosibirsk, SO RAN. 2001. 359 p. (in Russ.) [Юхин Ю.М., Михайлов Ю.И. Химия висмутовых соединений и материалов. Новосибирск, СО РАН, 2001. 359 с.].

3. Mashkovsky M.D. Medications. Moscow: Meditsina. 1993. Vol. 1. 390 (in Russ.) [Машковский М.Д. Лекарственные средства, Т. 1. М.: Изд-во Медицина, 1993. 390 с.].

4. Lipengolts A.A., Cherepanov A.A., Grigor'eva E.Yu., Kulakov V.N. Rossiysky Bioterapevtichesky Zh. 2016, 15(1), 58 (in Russ.).

5. Treibs A. Lieb. Ann. Chem. 1969. B. 728, 115-143.

6. Buchler J.W., Lay K.L. Inorg. Nucl. Chem. Lett. 1974, 10, 297-300.

7. Dehghani H., Ansari S., Ali R. Bull. Chem. Soc. Japan. 2007, 80, 518-522.

8. Michaudet L., Fasseur D., Guilard R., Ou Z., Kadish K.M., Dahaoui S., Lecomte C. J. Porphyrins Phthalocyanines 2000, 4, 261-270.

9. Lemon C.M., Brothers P.J., Boitrel B. Dalton Trans. 2011, 40, 6591-6609.

10. Le Gac S., Najjari B., Motreff N., Remaud-Le Saec P., Faivre-Chauvet A., Dimanche-Boitrel M., Morgenstern A., Bruchertseifer F., Lachkar M., Boitrel B. Chem. Commun. 2011, 47, 8554-8556.
11. Yang N., Tanner J.A., Wang Z., Huang J.-D., Zheng B.-J., Zhu N., Sun H. Chem. Commun. 2007, 4413-4415.

12. Gomes M.L., De-Freitas-Silva G., Reis P.G., Melo M.N., Frezard F., Demicheli C., Idemori Y.M. J. Biol. Inorg. Chem. 2015, 20, 771-779.

13. Valicsek Z., Horvath O., Patoney K. J. Photochem. Photobiol. A: Chemistry 2011, 226, 23-35.

14. Golubev D.V., Rumyantseva V.D., Fomichev V.V. Tonkie Khim. Tekhnol. 2017, 12, 26-30 (in Russ.).

15. Laikov D.N. Chem. Phys. Lett. 2005, 416, 116-120.

16. Laikov D.N. Chem. Phys. Lett. 1997, 281, 151-156.

17. Laikov D.N., Ustynyuk Yu.A. Russ. Chem. Bull., Int. Ed. 2005 $54,820-82$.

18. Smith K.M. Porphyrins and Metalloporphyrins. Elsevier. Amsterdam-Oxford-New York. 1975, p. 800.

19. Koifman O.I., Semeikin A.S., Berezin B.D. In: Porphyrins: Structure, Propertties, Synthesis (Enikolopyan N.S., Ed.). Moscow: Nauka, 1985. 205-212 (in Russ.) [Койфман О.И., Семейкин А.С., Березин Б.Д. В кн.: Порфирины. структура, свойства, синтез (Ениколопян Н.С., ред.). М.: Наука, 1985. 205-212].

20. Lindsey J.S., Schreiman I.C., Hsu H.C., Kearney P.C., Marquerettaz A.M. J. Org. Chem. 1987, 52, 827-836.

Received 23.01.2018 Accepted 02.03.2018 